Stanford when assessing the quality of Ph.D. graduates.

5. We thank the APSA office for generously allowing us to use the older directories.

6. Dissertation Abstracts Ondisc is a single database that combines information from the Comprehensive Dissertation Index, Dissertation Abstracts International, American Doctoral Dissertations and Masters Abstracts International. Dissertations from 1861 to present are in the database.

7. The authors on whom we were unable to locate biographical data fall into four major categories: they are either from other disciplines, from foreign universities, from nonacademic institutions, or they have recently retired. The reason for the larger percentage of missing data on biographical information for the earlier twenty-year period is because during that time, fewer authors were members of the APSA and more of them appeared to be from outside the United States.

8. For example, we identified a total of sixty-three authors from $D A O$ that received their Ph.D.'s in other disciplines. Our data also showed a total of 42 authors listed at non-academic institutions (e.g., Brookings Institution) in 1994 or 1973.

9. A school receives credit for a publication when a faculty member publishes in the $A P S R$, regardless of whether it was a singleauthored or multi-authored article. Thus, if a team of four collaborators are all from the same school that school gets credit for four publications.

10. The equation for the Gini coefficient is, $\mathrm{G}=1+1 / \mathrm{N}-\left[2\left(\mathrm{x}_{\mathrm{N}}+2 \mathrm{x}_{\mathrm{N}}+3 \mathrm{x}_{\mathrm{N}-2}+\right.\right.$ $\left.\ldots+N x_{1}\right) / N^{2} \mu$ ], where $N$ equals the number of APSR authors in the department, $x_{N}$ is the highest number of APSR publications in a department and $x_{1}$ is the smallest, and $\mu$ equals the mean number of APSR publications in the department.

11. The purpose here was to determine to what extent the APSR publications were uniformly distributed across the authors who had contributed to the Review rather than determining to what extent the articles were distributed across all the members of each department. If we included all members of each department who have no APSR publications, the coefficients would be much higher. The coefficient values are also surpressed by the fact that very few individuals in the profession publish five or more APSR articles. As a result of how difficult it is to publish in the Re- view, few departments will ever have a highly skewed distribution for the number of APSR publications contributed by those who published at least once in the Review, hence Gini coefficients for the number of articles in the APSR should be relatively low.

12. The PVI is calculated by multiplying publications by citations and then dividing by 1,000 .

13. It might be argued that the PVI, as we calculated it (number of APSR articles times the number of citations), is dominated by the weight of the citations. To examine this possibility we produced another ranking after setting publication counts equal to citation counts and adding the two numbers together. Setting publications equal to citations was accomplished by dividing the mean number of citations by the mean number of publications, then multiplying the number of publications times the resulting number (185.64). The new ranking with equally weighted publication and citation counts is virtually the same as our original ranking, no doubt because number of publications and number of citations are correlated.

14. The number of $A P S R$ articles for the faculty comes from Tables 3 and 4 . The number of articles produced by the graduates of a department comes from Table 5. To compute the number of citations used to calculate the PVI in Table 6 , add the number of articles from Tables 3 (or 4 depending on the time period) and 5 , then divide the PVI value in Table 6 (after multiplying by 1000) by the number of articles. For example, to calculate the combined number of citations for Harvard, add 43 articles from Table 3 for 1994 and 44 articles from Table 5 for a total of 87 articles. Multiply the Table 6 PVI (3661.24) by 1000 and divide by 87 for a total of 42,083 citations. Interested readers can write the senior author to request these values and the PVI values for the fuller set of schools included in the data.

\section{References}

Christensen, James A. and Lee Sigelman. 1985. "Accrediting Knowledge: Journal Stature and Citation Impact in Social Science." Social Science Quarterly 66:964-76.

Fenton, David W. 1995. "Apparent Anomalies in Reported Data for the Field of Music in the Report of the National Research Council." This report can be accessed at the following World Wide Web site: http:// www.bway.net/-dfenton/nrc-report/nrcrept.html.

Garand, James C. 1990. "An Alternative Interpretation of Recent Political Science Journal Evaluations." Political Science and Politics 23:444-51.

Jackman, Robert W. and Randolph M. Siverson. 1996. "Rating the Rating: An Analysis of the National Research Council's Appraisal of Political Science Ph.D.

Programs." Political Science and Politics 29 (June): 155-60.

Katz, Richard S. and Munroe Eagles. 1996 "Ranking Political Science Programs: A View from the Lower Half." Political Science and Politics 29 (June): 149-54.

Klingemann, Hans-Dieter. 1986. "Ranking the Graduate Departments in the 1980s: Toward Objective Qualitative Indicators." Political Science and Politics 19:651-61.

Lambert, Peter J. 1989. The Distribution and Redistribution of Income: $A$ Mathematical Analysis. Cambridge: Basil Blackwell.

Lowery, Robert C. and Brian D. Silver. 1996. "A Rising Tide Lifts All Boats: Political Science Department Reputation and the Reputation of the University." Political Science and Politics 29 (June): 161-67.

Magner, Denise. 1995. "Ratings War: A New Ranking of Doctoral Programs Spurs a Flurry of Departmental Damage Control." Chronicle of Higher Education, October 27, A19.

Miller, Arthur H., Charles Tien and Andrew Peebler. 1996. "The American Political Science Review Hall of Fame: Assessments and Implications for an Evolving Discipline." Political Science and Politics 29 (March) 73-83.

National Research Council (NRC). 1995. Re search Doctorate Programs in the United States: Continuity and Change. Washington DC: National Academy Press.

Robey, J. S. 1982. "Reputation vs. Citations: Who are the Top Scholars in Political Science?" Political Science and Politics 15: 199-200.

Welch, S. and J. R. Hibbing. 1983. "What Do the New Ratings of Political Science Departments Measure?" Political Science and Politics 16:532-40.

\title{
A Political Scientist Rides the Talk Radio Circuit
}

\author{
James G. Gimpel, University of Maryland
}

Old geezers sitting around in barber shops listening to cattle market and farm commodity reports, grousing about community problems, and bragging about their latest hunting and fishing expeditions. That's my vision of AM talk radio listeners formed by my childhood upbringing in a small western Nebraska town. Growing up, I figured the only reason why people listened to talk radio was because there were only three radio stations on the dial in my remote part of an out-of-the-way state. So when my publisher, Allyn and Bacon, decided to hire a publicist to promote my book on the first 100 days of the 104th Congress and the 
talk radio producers began requesting interviews, my first thought was, "these folks don't buy books, least of all books about Congress! They probably can't even read."

\section{Talk Radio Inundation}

Maybe talk radio listeners don't read-and I do have sincere doubts about whether the radio interviews I have done sold many books-but the requests for talk show interviews started flowing only a week after publication: Houston, Colorado Springs, Hartford, Worcester, St. Louis, State College (PA), Columbus, San Antonio. Toledo, Wichita, Houston, Dallas, Charleston, Bakersfield, Dallas (again) and Denver the next week. My appearances (usually over the phone) lasted between 10 minutes and an hour (including commercial breaks). I was on the air all times of the day and some evenings.

Usually, the publicist would first make contact with a talk show producer and schedule a time for the interview. Most of the shows would call my office a few minutes before the interview began but after regular working hours I sent many of them to my home number. Some hosts would call me several days in advance of the scheduled interview time for an impromptu "audition." One Omaha host explained that he wanted to make sure I wasn't another boring academic.

So what accounted for the $50 \mathrm{ra-}$ dio interviews I did in March, April and May of this year? I would like to think that it is the content of the book. But somehow I don't think the book's content is the reason for the tidal wave of publicity. Nor is it the slick operation my publicist runs for Allyn and Bacon. Allyn and Bacon has little experience with "trade" books. They're primarily a text publisher. Their sales force does not even call on bookstores. Did the book hit the market at the ideal time, just before primary season? Yes. That certainly helped publicity.

But the key reason, I suspect, for the interest of the talk show hoards is that beleaguered hosts are desperate to fill air time. Imagine trying to fill 365 days a year, 12-24 hours a day, with talk. This is a tall order and I just happened to be there, along with dozens of other authors, to help them do their job.

\section{Talk Radio as Entertainment}

Politics has great entertainment value and it only takes a few shows to learn that radio hosts are not serious journalists. They are entertainers. They often use ideological extremism on the left or right to provoke their audience. Left-wingers pushed me to give-in and admit that the Republicans were cruel and "out to starve" some people. Other hosts would have felt victorious had I admitted that the Republican revolution was dead. Since political ideology is an instrument of entertainment, guests that make controversial points are especially attractive. Many hosts were inevitably disappointed when I provided a straightforward political science-ish assessment of the Contract with America and its prospects for passage. On several stations, the hosts deliberately tried to pick a fight with me, no doubt to hold their audience with concocted controversies.

When confronted by an argumentative host, one has two choices: either play along and argue or concede the host's points. Usually, when I argued, I lost. Talk radio hosts are not hired because they can easily be defeated in an argument. Hosts delight in pushing their guests to stray from the facts to editorialize and speculate. This contributes to talk radio's tabloid quality: the wilder the speculation, the better.

After awhile, the temptation to editorialize became so strong, I gave in on several occasions, often contradicting my remarks on shows the previous day. Consistency in punditry, I learned, is a real talent-and one that I do not have. Nor did I have the time to give complete explanations on the air. On a Dallas evening show, Congressman Joe Barton (R-TX) called to set me straight on things I failed to explain in my answers to earlier callers. He ended his ten minute effort to set the record straight by endorsing the book, so I didn't mind.

\section{Assailed by Ideologues}

Michael Traugott and his colleagues have found that a plurality of the talk radio audience is Republican and conservative (Traugott, et al., 1996). My experience was that most of the shows played to conservative audiences but there were liberal audiences too: for example, KGO in northern California; WMSX in Brockton, MA; WKDR in Burlington, VT; and WHMP in Northampton, MA. On one California station, I had the distinction of following a full hour program on astrology. But I guess moving from astrology to politics is no oddity in California, nor in Washington, where "spiritual advisers" have become adjunct advisers at the White House. Undoubtedly, the listeners were disappointed when I admitted that, to my knowledge, the stars played no role in the formation of the Contract. I had no callers after that remark.

I was attacked from the right in Phoenix and Bakersfield by rabid Buchanan supporters who resented my quite reasonable belief that Bob Dole was going to be the Republican nominee. The Montgomery, AL talk show host, also a die-hard fan of Patrick Buchanan, abruptly ended the interview and hung up after I suggested that Bob Dole made a good-faith effort to bring Contract items up for a vote in the Senate. This shocked my moralistic midwestern sensibilities, but I have since learned that such derision is standard talk radio fare.

On the left-wing stations, like the one in Burlington, Vermont, I was assailed by liberal callers who insisted that the "Contract was a bunch of malarky and that President Clinton was going to win in a landslide!" To which I replied to one caller, "In Burlington, it probably will be a landslide." Not much room for sober political science analysis on these shows. How naive for me to think I could just talk facts. There are no facts on talk radio, only opinions. And my mind simply was not made up on enough issues.

Occasionally, even moderates attacked me. In one large city, I explained how political scientists find that swing voters are generally less 
interested and less informed about politics than partisan voters. Wow! Did that ever set off a firestorm of calls from listeners claiming to be both informed and independent! I probably wound up losing that station about $\$ 300,000$ in advertising despite my assurance to these callers that there are exceptions to the generalization. Of course, many of these topics were entirely tangential to the Contract, and to my book, but that doesn't matter on entertainment radio.

Although I have not studied the demographics of talk radio listenership, my childhood impression of old guys sitting around in barbershops is surely incorrect. My anecdotal experience confirms Traugott's research (1996) - that the audience is about as variable as the nation itself with an accent on the extremes. The shows on which I appeared were a mix of liberal and conservative, and the callers were truly all over the map in terms of information and political inclination, but there were far more callers on both the far right and far left than in the middle.

\section{Anticipating the Audience: The Political Geography of Talk Radio}

Trying to anticipate the ideological bent of the callers is helpful. After awhile, I learned to ask the producers of the shows about the ideological inclinations of their audi- ence so I would know what to expect. My basic knowledge of American political geography also served as a good predictor. Southern stations were by far the most conservative. With a few exceptions, northeastern stations played to more liberal audiences. Midwestern stations seemed to play right down the middle. The book was treated most fairly by stations in Denver, Topeka, Grand Forks, Omaha, and Madison, WI. The callers and hosts on these shows were less interested in scoring political points. One midwestern caller actually thanked me for my objectivity. I was so shocked, I nearly choked on the air!

Maintaining your enthusiasm through the ordeal of repeated interviews is a real battle of the will. On some days, I spent five hours doing talk radio interviews. Often, I could not remember what points I made on one show, and which points I made on the one before. I tried to keep a list of talking points in front of me, and this did help, but one show tended to fade into another. Sounding like a broken record is a great way of boring the audience and losing advertising dollars for the station, as I learned when one host cut me off after 45 minutes for harping too long on one theme.

\section{Making Money or Just for Fun}

The whole point of publicity, of course, is to sell books. Why else would anyone consent to such abuse? Research shows that listening does make people more attentive to domestic news (Traugott 1996), but, again, do talk radio listeners actually buy books?

I think I earned about $\$ 30.00$ in book royalties for every hour I spent on talk radio. But since I have no clue how many books would have sold without the publicity, I justify the time by confessing that riding the talk radio circuit was fun-another experience to share in the classroom and impress the folks back in Nebraska.

\section{Reference}

Traugott, Michael, et al. 1996. "The Impact of Talk Radio on its Audience," Paper Presented at the annual meeting of the Midwest Political Science Association, Chicago, IL.

\begin{abstract}
About the Author
James Gimpel is assistant professor of government and politics at the University of Maryland in College Park. He has published two books, Legislating the Revolution (Allyn and Bacon, 1996) and National Elections and the Autonomy of American State Party Systems (University of Pittsburgh Press, 1996). He has also published articles on voting, Congress, and public opinion.
\end{abstract}

\title{
Researching Congress
}

\author{
Joseph K. Unekis, Kansas State University
}

New faculty or advanced graduate students who wish to pursue research on Capitol Hill, but who lack resources or experience, are often unsure how to accomplish the task. So here are some observations designed to help them get more out of their time and energy.

For most faculty on three-two, three-three, or even worse teaching schedules, finding the time to visit Washington usually means giving up some summer vacation. However, do not automatically write off other times of the year. The winter break is also good because faculty can usually squeeze out almost three weeks in early January. As a bonus, it is easier to deal with staff at this time because little else is on their agenda.

Once time is freed-up for research, make sure this is a good time for the people who have the information you seek. Interviewing members or high level staff requires knowledge of the Congressional schedule, especially the recess peri- 